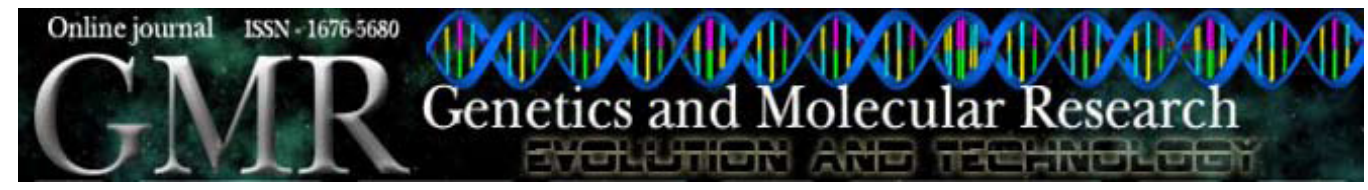

\title{
Genetic characterization of heat tolerant tomato (Solanum lycopersicon) genotypes by SRAP and RAPD markers
}

\author{
N. Comlekcioglu' ${ }^{1}$, O. Simsek ${ }^{2}$, M. Boncuk ${ }^{3}$ and Y. Aka-Kacar ${ }^{2,3}$ \\ ${ }^{1}$ Department of Horticulture, Faculty of Agriculture, Harran University, \\ Sanliurfa, Turkey \\ ${ }^{2}$ Department of Horticulture, Faculty of Agriculture, Cukurova University, \\ Balcali, Adana, Turkey \\ ${ }^{3}$ Biotechnology Department, Institute of Basic and Applied Sciences, \\ University of Cukurova, Balcali, Adana, Turkey \\ Corresponding author: N. Comlekcioglu \\ E-mail: nuray@harran.edu.tr
}

Genet. Mol. Res. 9 (4): 2263-2274 (2010)

Received July 12, 2010

Accepted September 8, 2010

Published November 23, 2010

DOI 10.4238/vol9-4gmr876

\begin{abstract}
We employed RAPD and sequence-related amplified polymorphism (SRAP) markers to evaluate polymorphisms in 15 tomato (Solanum lycopersicon) genotypes that were obtained from a tomato breeding program. Four local tomato genotypes selected from the Sanliurfa province (Southeastern Anatolia Region of Turkey), 10 heat-tolerant tomato genotypes, received from the Asian Vegetable Research and Development Center, and a sample of S. pimpinellifolium were genotyped with RAPD and SRAP markers. Eleven SRAP primer combinations were used and 66 bands were scored. The number of bands scored per primer combination ranged from three to 12 , with a mean of six alleles per primer combination. All fragments scored for each primer combination were polymorphic. The percentage of polymorphic products ranged from 25 to $80 \%$. The 15 tomato genotypes were screened for RAPD markers using 50 primers in a PCRbased DNA amplification procedure; 46 primers produced clear and good amplification. Ten of these 46 primers amplified monomorphic
\end{abstract}


fragments in the tomato genotypes. A dendrogram was constructed by combining data from the RAPD and SRAP analyses. Similarity ratios of genotypes ranged from 0.87 to 0.99 . The dendrogram was divided into two branches; the first main branch included only genotype CL 5915, and the second main branch included all the other genotypes.

Key words: Solanum lycopersicon; Heat tolerance; Molecular markers; Polymorphism; DNA fingerprinting; Genetic characterization

\section{INTRODUCTION}

Tomato (Solanum lycopersicon) is one of the most important and widely grown vegetable crops in both temperate and tropical regions of the world. In tropical and subtropical regions, heat stress may become a major limiting factor for the growth, reproduction and yield of tomato. Camejo et al. (2005) reported that the optimum temperatures for tomato cultivation are between $25^{\circ}$ and $30^{\circ} \mathrm{C}$ during the photoperiod and $20^{\circ} \mathrm{C}$ during the dark period. However, a $2-4^{\circ} \mathrm{C}$ increase over the optimal temperature adversely affects gamete development and inhibits the ability of pollinated flowers to develop into seeded fruits and thus reduced crop yield (Peet et al., 1997; Sato et al., 2001; Firon et al., 2006). At high temperatures most tomato cultivars have problems with fruit set, pollen meiosis and germination, ovule development and viability and development of the embryo (Peet et al., 1988). Seed germination, seedling and vegetative growth, flowering, fruit set, and fruit ripening are adversely affected at a temperature of above $35^{\circ} \mathrm{C}$ (Thomas and Prasad, 2003; Wahid et al., 2007). Heat tolerance is a critical character of tomato varieties targeted for production in the tropics and sub-tropics. Heat-tolerant tomatoes are reported to have the ability to set fruit at higher temperatures than other tomatoes (AVRDC, 2001). Selection of crops for tolerance to high temperature stress is proposed as the best and easiest strategy for breeding (Warner and Erwin, 2005).

The most important aim of plant breeding includes high yielding varieties that are resistant to biotic and abiotic stress factors. Plant genetic sources are the main material in breeding of new varieties suitable for stress conditions, ever-changing consumer demands and changing ecologic conditions with the effects of global warming (Strauss, 1991). Classical plant breeding generally involves the stages of releasing genetic variations and selection from the populations that show variation (Gepts, 2002). Local populations, which naturally evolved in nature over many years, are of great importance for selection. With the development of better and more efficient species in numerous types of plants, domestic species with higher genetic diversity and lower yield are replaced by commercial varieties and genetic diversity is reduced. Average global temperatures are increasing by approximately $0.3^{\circ} \mathrm{C}$ a decade. It is estimated that by the middle of the 21 st century, average temperatures will be $1.3-1.8^{\circ} \mathrm{C}$ higher than current values and $3-6^{\circ} \mathrm{C}$ higher by the end of the century (IPCC, 2001; Meehl et al., 2007). Temperature is the most important environmental factor affecting plant growth and yield (Houghton and Yihui, 2001). Temperature affects physiological, biochemical, morphological, and agronomic properties of plants. When the average temperature increases by $1.5-2.5^{\circ} \mathrm{C}, 20-30 \%$ of plant species will be endangered (Meehl et al., 2007). To minimize the negative impacts of high temperature genetic improvements are of profound importance. Lower genetic diversity is required to develop new species (Heywood et al., 2007 ). Therefore, 
it is important to characterize, conserve and utilize genetic sources (Barrero and Tanksley, 2004; Gepts, 2006). Since tolerance to abiotic stresses is complex, if the plant selection is made based on phenotypic conditions affected by environmental factors, this will result in a high level of misleading effects on breeding programs. Selection based on molecular markers is one of the most effective approaches in developing tolerance in plants (Foolad, 2007). Breeding studies should include plants with known genotypic properties, which are not affected by environmental conditions. Molecular marker techniques with high polymorphism can be used to identify similarity and differences between varieties and to identify parents, which can be used in breeding programs (Terzopoulos and Bebeli, 2008). The advantages and technological improvements recently offered by the new techniques should be used to conserve genetic resources and to use breeding activities in a more reliable, fast and efficient method. These techniques include molecular genetics, tissue culture and recombinant DNA technology.

DNA molecular marker technology provides powerful tools for cultivar identification in various crops with the advantages of being faster, less laborious and more efficient (Li-Wang et al., 2007).

Randomly amplified polymorphic DNA (RAPD) markers, resulting from the polymerase chain reaction (PCR) amplification of genomic DNA fragments using short oligonucleotides (usually 10-mers) of arbitrary sequence as primers, provide a fast and easy approach for many purposes in plant genetic analysis. For these reasons many fruit species have been successfully fingerprinted using RAPD markers (Aka-Kacar et al., 2005).

Sequence-related amplified polymorphism (SRAP) is a PCR-based marker system as described by Li and Quiros (2001). The SRAP is a simple and efficient marker system that can be adapted for a variety of purposes in different crops, including map construction, gene tagging, genomic and cDNA fingerprinting, and map-based cloning. It has several advantages over other systems. It is simple, has a reasonable throughput rate, discloses numerous co-dominant markers, targets open-reading frames (ORFs), and allows easy isolation of bands for sequencing (Uzun et al., 2009).

The aim of this study was to determine a genotypic characterization of tomato genotypes domestically planted in warm and arid climate conditions during tomato production season with RAPD and SRAP molecular marker programs, and to compare these with the genotypes resistant to heat provided by the Asian Vegetable Research and Development Center (AVRDC) to identify similarity of groups based on molecular markers with the aim of using them as a source of heat tolerance for the genetic improvement of tomato.

\section{MATERIAL AND METHODS}

\section{Plant materials}

Four local tomato (S. lycopersicon) genotypes (U-4-10, U-64-16, U-2-29, and U-117-2) selected from the Sanliurfa province, Southeastern Anatolia Region of Turkey (Soylu and Comlekcioglu, 2009), 10 heat tolerant tomato genotypes, CLN 2498 E, CLN 2001 A, CLN 1621 L, CLN 2418 A, CL 5915-93D4-1-0-3 (CL 5915), CLN 2413 R, BL 1173, BL 1174, BL 1175, BL 1176, received from the AVRDC and S. pimpinellifolium were used as plant materials in this study. Some morphological traits based on the Tomato Descriptors (IPGRI, 1996) are shown in Table 1. 


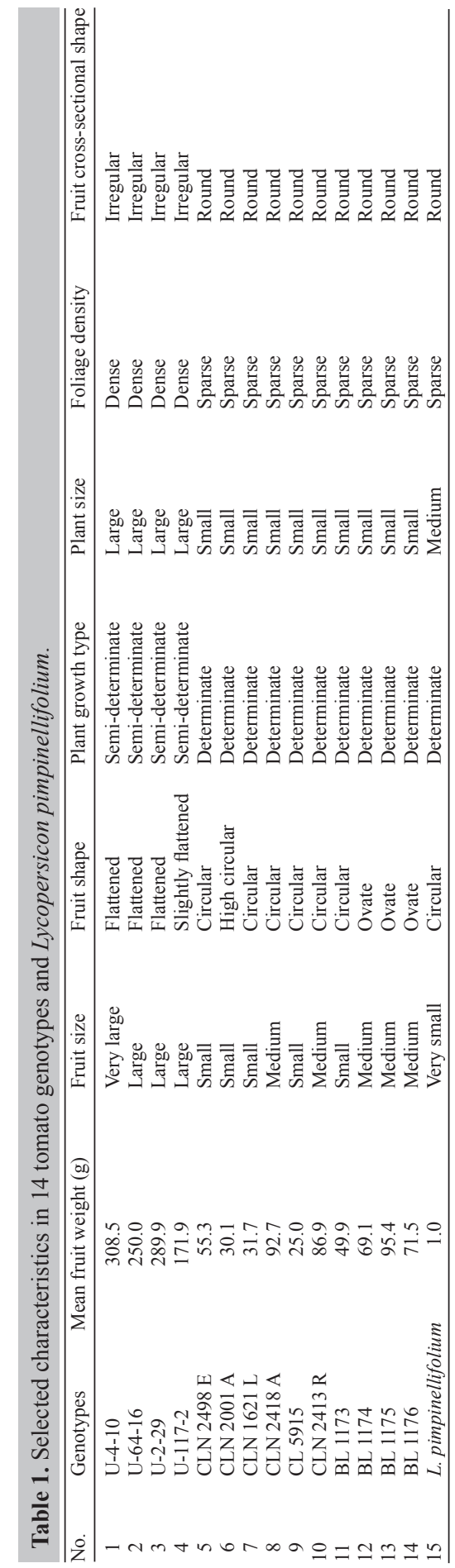




\section{Molecular analysis}

\section{DNA isolation}

Young leaves were collected from tomato genotypes and immediately frozen in liquid nitrogen and stored at $-80^{\circ} \mathrm{C}$. High molecular weight genomic DNA was extracted from the leaf samples following the protocol for minipreps by using CTAB (Edwards et al., 1991). DNA concentration was measured using a NanoDrop, ND 100 spectrophotometer (NanoDrop Technologies, Inc.) and gel electrophoresis. DNA was diluted in water to a final concentration of $50 \mathrm{ng} / \mu \mathrm{L}$ and stored at $-20^{\circ} \mathrm{C}$.

\section{SRAP analysis}

All SRAP primer combinations were initially screened with the genotypes (Table 2). The 11 primers that produced scorable polymorphic bands were used to amplify the rest of the accessions (Table 3 ). Amplification reactions were done in volumes of $22 \mu \mathrm{L}$ containing $2 \mathrm{X}$ PCR Mastermix (Fermantas K0171), 1 U Taq DNA polymerase (Fermentas EP0402), $\mathrm{MgCl}_{2}$, $25 \mathrm{mM}$ of each primer and $125 \mathrm{ng}$ tomato DNA. The mixtures were assembled at $0^{\circ} \mathrm{C}$, and then transferred to thermal cycler, precooled to $4^{\circ} \mathrm{C}$. The amplification was carried out in a model Master Gradient thermal cycler (Eppendorf) using a program consisting of an initial denaturation step of $5 \mathrm{~min}$ at $94^{\circ} \mathrm{C}$, and then 5 cycles of $1 \mathrm{~min}$ at $94^{\circ} \mathrm{C}, 1 \mathrm{~min}$ at $35^{\circ} \mathrm{C}, 2 \mathrm{~min}$ $72^{\circ} \mathrm{C}$, and then 35 cycles of $1 \mathrm{~min}$ at $94^{\circ} \mathrm{C}, 1 \mathrm{~min}$ at $50^{\circ} \mathrm{C}, 2 \mathrm{~min}$ at $72^{\circ} \mathrm{C}$, followed by a 10 -min elongation step at $72^{\circ} \mathrm{C}$. PCR products were stored at $4^{\circ} \mathrm{C}$ before analysis.

\begin{tabular}{ll} 
Table 2. The forward and reverse sequence-related amplified polymorphism primer information for this study. \\
\hline Forward primers & Reverse primers \\
\hline Me1: TGAGTCCAAACCGGATA & Em1: GACTGCGTACGAATTAAT \\
Me2: TGAGTCCAAACCGGAGC & Em2: GACTGCGTACGAATTTGC \\
Me8: TGAGTCCAAACCGGACT & Em3: GACTGCGTACGAATTGAC \\
Me10: TGAGTCCAAACCGGAAA & Em4: GACTGCGTACGAATTTGA \\
& Em5: GACTGCGTACGAATTAAC \\
& Em13: GACTGCGTACGAATCTG \\
& Em14: GACTGCGTACGAATCTT \\
& Em15: GACTGCGTACGAATTGAT \\
& Em16: GACTGCGTACGAATGTC \\
\hline
\end{tabular}

The amplification products were separated by electrophoresis on $2.5 \%$ agarose gels and $0.5 \mathrm{~g} / \mathrm{mL}$ ethidium bromide in $1 \mathrm{X}$ TAE buffer (40 mM Tris-acetate, $1 \mathrm{mM}$ EDTA, $\mathrm{pH}$ 8.0) for 3.5 $\mathrm{h}$ at $110 \mathrm{~V}$. The fragment patterns were photographed under UV light for further analysis. A 100-bp DNA ladder was used as the molecular standard in order to confirm the appropriate SRAP markers.

\section{RAPD analysis}

Fifty RAPD primers (from sets of OPA, OPAE, OPAF, OPAI, OPAJ, OPAK, OPE, and OPX; Operon Technologies, Almeda, CA, USA) were used initially on accessions (Table 4). Primers that produced polymorphic bands were used to amplify all 15 genotypes studied. Thirty-six 10-mer primers found to be polymorphic (Table 4) were used to generate RAPD markers.

Amplification reactions were done in 9- $\mu \mathrm{L}$ volumes containing $2 \mathrm{X}$ PCR Mastermix 
(Fermantas K0171), 1 U Taq DNA polymerase (Fermentas EP0402), $\mathrm{MgCl}_{2},(25 \mathrm{mM}) 30 \mathrm{ng}$ of the primer and $15 \mathrm{ng}$ tomato DNA. The mixtures were assembled at $0^{\circ} \mathrm{C}$, and then transferred to a thermal cycler, precooled to $4^{\circ} \mathrm{C}$. The amplification was carried out in a model Master Gradient thermal cycler (Eppendorf) using a program consisting of an initial denaturation step of $2 \mathrm{~min}$ at $94^{\circ} \mathrm{C}$, and then 45 cycles of $2 \mathrm{~min}$ at $94^{\circ} \mathrm{C}, 1 \mathrm{~min}$ at $37^{\circ} \mathrm{C}, 2 \mathrm{~min}$ at $72^{\circ} \mathrm{C}$, followed by a 10 -min elongation step at $72^{\circ} \mathrm{C}$. PCR products were stored at $4^{\circ} \mathrm{C}$ before analysis.

The amplification products were separated by electrophoresis on $1.5 \%$ agarose gels and $0.5 \mathrm{~g} / \mathrm{mL}$ ethidium bromide in $1 \mathrm{X}$ TAE buffer (40 mM Tris-acetate, $1 \mathrm{mM}$ EDTA, $\mathrm{pH}$ 8.0) for $3 \mathrm{~h}$ at $70 \mathrm{~V}$. The fragment patterns were photographed under UV light for further analysis. A 1-kb DNA ladder was used as the molecular standard in order to confirm the appropriate RAPD markers.

\section{Data analysis}

Reproducible SRAP and RAPD profiles were scored manually in the binary mode with 1 indicating the presence, and 0 indicating the absence of a band. SRAP and RAPD analysis results were combined. The unweighted pair-group method using the arithmetic average clustering procedure (UPGMA) was employed to construct the clustering dendrograms based on the genetic distance matrix using the NTSYS-PC program (version 2.02i) (Rohlf, 1998). The representativeness of the dendrogram was evaluated by estimating the cophenetic correlation for the dendrogram and comparing it with the similarity matrix, using Mantel's matrix correspondence test (Mantel, 1967). The result of this test is a cophenetic correlation coefficient, indicating how well the dendrogram represents similarity data.

\section{RESULTS AND DISCUSSION}

\section{SRAP analysis}

A total of 11 SRAP primer combinations were used and a total of 66 bands were scored. The number of bands scored per primer combination ranged from 3 (Me8Em1, Me8Em13, Me8Em16) to 12 (Me1Em4, etc.), with a mean of 6 alleles per primer combination. All fragments scored for each primer combination were polymorphic. The percentage of polymorphic products ranged from 25\% (Me10Em5) to 80\% (Me10Em16) (Table 3).

\begin{tabular}{|c|c|c|c|c|}
\hline SRAP primer combinations & Size range (bp) & Total number of bands & Polymorphic bands & Polymorphism (\%) \\
\hline $\mathrm{Me} 1 \mathrm{Em} 4$ & $220-1050$ & 12 & 5 & $41.6 \%$ \\
\hline $\mathrm{Me} 2 \mathrm{Em} 3$ & $500-1050$ & 5 & 2 & $40.0 \%$ \\
\hline Me8Em1 & $510-790$ & 3 & 2 & $66.6 \%$ \\
\hline Me8Em13 & $350-500$ & 3 & 2 & $66.6 \%$ \\
\hline Me8Em15 & $300-1050$ & 9 & 3 & $33.3 \%$ \\
\hline Me8Em16 & $150-800$ & 3 & 2 & $66.6 \%$ \\
\hline $\mathrm{Me} 10 \mathrm{Em} 2$ & $250-1000$ & 5 & 2 & $40.0 \%$ \\
\hline $\mathrm{Me} 10 \mathrm{Em} 5$ & $210-580$ & 4 & 1 & $25.0 \%$ \\
\hline Me10Em14 & $220-1010$ & 10 & 5 & $50.0 \%$ \\
\hline Me10Em15 & $250-1050$ & 7 & 2 & $28.5 \%$ \\
\hline Me10Em16 & $210-800$ & 5 & 4 & $80.0 \%$ \\
\hline Total & $150-1050$ & 66 & 28 & $42.42 \%$ \\
\hline
\end{tabular}




\section{RAPD analysis}

Fifteen tomato genotypes were screened for RAPD markers using 50 primers in a PCR-based DNA amplification procedure. Forty-six primers produced a clear and good amplification. Ten of the remaining forty-six primers amplified monomorphic fragments for the tomato genotypes studied (OPA-04, OPA-13, OPA-19, OPE-09, OPAK-14, OPX-07, OPX-12, OPX-13, OPX-15, and OPX-18). Therefore, these primers were uninformative for distinguishing among the tomato genotypes.

Thirty-six 10-mer primers, which produced polymorphic bands were used to generate RAPD markers with all genotypes (Table 4). Among 208 bands generated by 36 selected RAPD primers, $55.3 \%$ were monomorphic, i.e., present in all individuals. The remaining $44.7 \%$ of variable bands were selected as RAPD markers. The mean number of polymorphic bands per primer was lower than that obtained by other researchers (Carelli et al., 2006). The low degree of polymorphisms indicated that there is low divergence between the genotypes studied.

\begin{tabular}{|c|c|c|c|c|c|}
\hline RAPD primer $^{a}$ & Sequence & Size range (bp) & Total number of bands & Polymorphic bands & $\begin{array}{l}\text { Products detecting } \\
\text { polymorphism }(\%)\end{array}$ \\
\hline OPA-09 & GGGTAACGCC & $300-1200$ & 8 & 4 & $50.0 \%$ \\
\hline OPA-14 & TCTGTGCTGG & $600-1600$ & 4 & 3 & $75.0 \%$ \\
\hline OPA-15 & TTCCGAACCC & $650-1250$ & 4 & 1 & $25.0 \%$ \\
\hline OPA-17 & GACCGCTTGT & $350-1500$ & 5 & 3 & $60.0 \%$ \\
\hline OPA-18 & AGGTGACCGT & $375-1220$ & 8 & 1 & $12.5 \%$ \\
\hline OPAE-10 & CTGAAGCGCA & $500-1200$ & 5 & 3 & $60.0 \%$ \\
\hline OPAE-17 & GGCAGGTTCA & $750-1500$ & 4 & 2 & $50.0 \%$ \\
\hline OPE-10 & CACCAGGTGA & $700-1700$ & 5 & 2 & $40.0 \%$ \\
\hline OPE-15 & ACGCACAACC & $480-1300$ & 6 & 2 & $33.3 \%$ \\
\hline OPE-17 & CTACTGCCGT & $375-1400$ & 3 & 1 & $33.3 \%$ \\
\hline OPE-20 & AACGGTGACC & $470-1050$ & 6 & 1 & $16.7 \%$ \\
\hline OPAF-04 & TTGCGGCTGA & $400-1900$ & 7 & 6 & $85.7 \%$ \\
\hline OPAF-07 & GGAAAGCGTC & $240-1700$ & 10 & 2 & $20.0 \%$ \\
\hline OPAF-09 & CCCCTCAGAA & $250-2100$ & 8 & 7 & $87.5 \%$ \\
\hline OPAJ-03 & AGCACCTCGT & $600-1550$ & 5 & 3 & $60.0 \%$ \\
\hline OPAJ-11 & GAACGCTGCC & $350-1250$ & 5 & 3 & $60.0 \%$ \\
\hline OPAK-05 & GATGGCAGTC & $380-1000$ & 6 & 4 & $66.7 \%$ \\
\hline OPAK-09 & AGGTCGGCGT & $675-1260$ & 6 & 2 & $33.3 \%$ \\
\hline OPAK-12 & AGTGTAGCCC & $250-1050$ & 6 & 1 & $16.7 \%$ \\
\hline OPAK-17 & CAGCGGTCAC & $500-1020$ & 5 & 1 & $20.0 \%$ \\
\hline OPAK-19 & TCG CAG CGAG & $250-1250$ & 7 & 3 & $42.9 \%$ \\
\hline OPAI-18 & TCGCGGAACC & $800-1100$ & 3 & 1 & $33.3 \%$ \\
\hline OPAI-20 & СCTGTTCCCT & $750-1100$ & 4 & 3 & $75.0 \%$ \\
\hline OPX-02 & TTCCGCCACC & $480-1000$ & 6 & 3 & $50.0 \%$ \\
\hline OPX-04 & CCGCTACCGA & $580-1500$ & 6 & 1 & $16.7 \%$ \\
\hline OPX-05 & ССТТТСССТС & $510-1255$ & 5 & 2 & $40.0 \%$ \\
\hline OPX-06 & ACGCCAGAGG & $450-1170$ & 5 & 2 & $40.0 \%$ \\
\hline OPX-08 & CAGGGGTGGA & $400-1230$ & 7 & 4 & $57.1 \%$ \\
\hline OPX-09 & GGTCTGGTTG & $530-1250$ & 6 & 2 & $33.3 \%$ \\
\hline OPX-10 & CCCTAGACTG & $675-1400$ & 6 & 2 & $33.3 \%$ \\
\hline OPX-11 & GGAGCCTCAG & $750-1100$ & 4 & 2 & $50.0 \%$ \\
\hline OPX-14 & ACAGGTGCTG & $400-1200$ & 8 & 4 & $50.0 \%$ \\
\hline OPX-16 & CTCTGTTCGG & $450-1600$ & 5 & 2 & $40.0 \%$ \\
\hline OPX-17 & GACACGGACC & $500-1400$ & 7 & 4 & $57.1 \%$ \\
\hline OPX-19 & TGGCAAGGCA & $400-1450$ & 6 & 1 & $16.7 \%$ \\
\hline OPX-20 & CCCAGCTAGA & $400-1450$ & 7 & 5 & $71.4 \%$ \\
\hline Total & & $240-1900$ & 208 & 93 & $44.7 \%$ \\
\hline
\end{tabular}

${ }^{\mathrm{a}}$ Marker notation refers to the kit (last letter) and the primer (-number) purchased from Operon Technologies (OP). 
The number of amplified DNA products depended on genotype primers. Although the number of bands for each primer varied from 3 (OPE-17, OPAI-18) to 10 (OPAF-07) with an average of 5.47 bands per primer, the sizes of the amplified DNA bands ranged from 240 (OPAF-07) to 2100 (OPAF-09) bp. Primers differed in their capacity to detect polymorphism (Figure 1). The percentage of polymorphic products ranged from $12.5 \%$ (OPA-18) to $85.7 \%$ (OPAF-04) (Table 4 ).

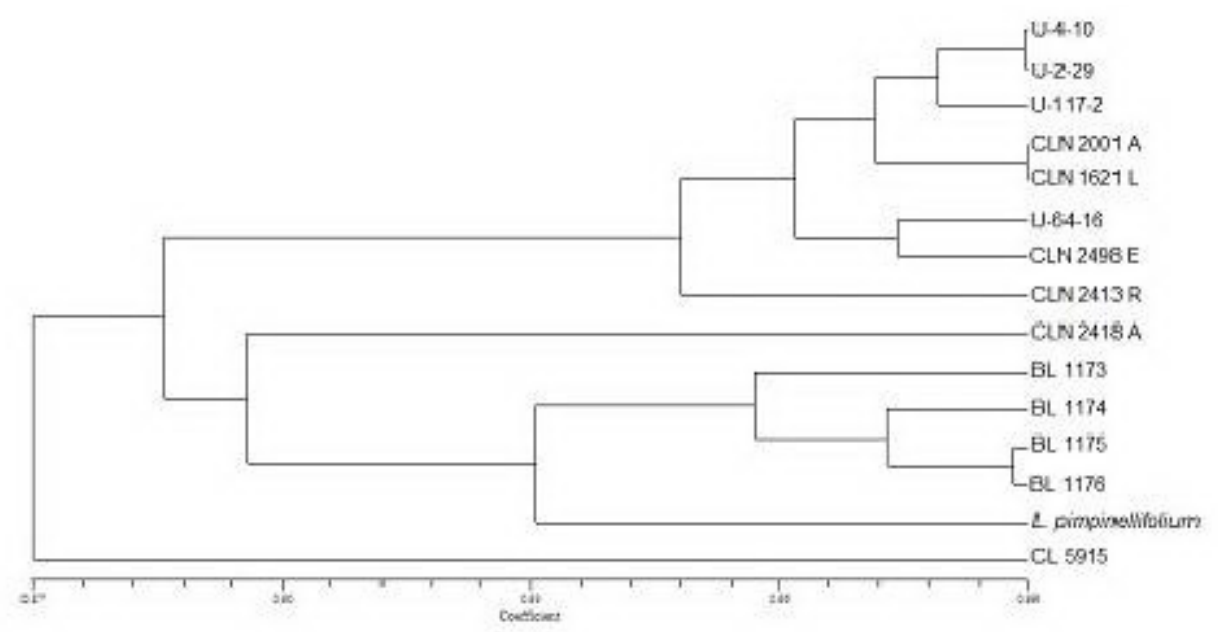

Figure 1. UPGMA dendrogram of 15 tomato genotypes from SRAP and RAPD data. Similarity values are shown at the bottom of the dendrogram.

\section{Phylogenetic analysis}

A dendrogram was formed by combining the data obtained from RAPD and SRAP analyses. Similarity ratio of the genotypes varied between 0.87 and 0.99 in the dendrogram (Figure 1). Variation was found to be low among genotypes under study. The most important reason for this is that except for $S$. pimpinellifolium, all genotypes belonged to the same species (S. lycopersicon) and were selected as heat-resistant genotypes. The dendrogram was numbered as 1 and 2 and was divided into two branches. While main branch No. 1 included only genotype CL 5915, main branch No. 2 included all the other genotypes used in the study. It was found that genotype CL 5915 in main branch No. 1 genetically resembled all other genotypes in main branch No. 2 at a ratio of $87 \%$ and deviated from those genotypes at a ratio of 13\%. Tomato line CL 5915 (CL 5915-93D4-1-0-3) was determined to be a valuable source of heat tolerance genes for tomato genetic improvement at AVRDC by evaluating the fruitset characters (AVRDC, 2001). Except for S. pimpinellifolium, CL 5195 had the lowest fruit weight among all genotypes in the study. Branch No. 2 was further divided into two branches: 2.1 and 2.2. Branch 2.1 included CLN 2418 A, BL 1173, BL 1174, BL 1175, BL 1176, and S. pimpinellifolium; branch 2.2 included U-4-10, U-64-16, U-2-29, U-117-2, CLN 2498 E, CLN 2001 A, CLN 1621 L, and CLN 2413 R genotypes. Since genotypes U-4-10, U-64-16, U-2-29, and U-117-2 were selected from the same area, it was an expected result for them to have the same genotypic characteristics and to be included in the same group. The genotypes in 2.1 and 2.2 branches were found to be approximately $89 \%$ similar to each other. S. pimpinellifolium, on the 2.1 branch, was different from other genotypes in this group. This was an expected result 
since this genotype was a different species. However, although this genotype is a different species, it resembled other genotypes in this group by $93 \%$. This might have occurred for two reasons. The first one is that there is low genetic variation in tomato (Alvarez et al., 2001) and the second one is that the marker systems used in the study might have failed to amplify the different regions. Our findings are consistent with those of Alvarez et al. (2001). Higher levels of genetic diversity in the self-incompatible species (S. peruvianum, S. hirsutum, S. pennel$l i i$, and $S$. chilense) than the self-compatible species (S. esculentum, S. pimpinellifolium, $S$. cheesmanii, S. parviflorum, and S. chmielewskii) have been reported (Miller and Tanksley, 1990; Breto et al., 1993). S. lycopersicon is self-compatible and inbreeding. S. pimpinellifolium populations are self-compatible and although some populations are autogamous and highly uniform in morphological terms, some populations have varying rates of outbreeding. Although fruit seeds were smaller than $S$. lycopersicon, they are morphologically very similar. $S$ pimpinellifolium can be reciprocally hybridized with $S$. lycopersicon and it is the only species showing natural introgression with S. esculentum (Taylor, 1986). DNA markers are derived from a small region of DNA that shows sequence polymorphism between individuals within or between species and they often do not allow detection of polymorphism within the cultivated species or between the cultivated species and closely related species such as $S$. pimpinellifolium (Miller and Tanksley, 1990; Saliba-Colombani et al., 2000).

According to the dendrogram formed by the comparison of RAPD and SRAP analysis data, no genetic difference was identified between U-4-10 and U-2-29, and CLN 2001 A and CLN 1621 L genotypes. U-4-10 and U-2-29 genotypes are two separate genotypes selected from the domestic population. These genotypes were found to be very similar in terms of fruit characteristics. Genotype No. U-117-2 in the dendrogram was different from genotypes U-410 and U-2-29. As indicated in the table, this genotype is slightly different from the other two genotypes in terms of morphology. Since genotype U-117-2 was selected from the same population as genotypes U-4-10 and U-2-29, it was an expected result for these genotypes to be in the same branch. Genotypes CLN 2001 A and CLN 1621 L were both taken from the gene bank as genotypes that are resistant to heat; they show slight differences in terms of fruit weight and form. Autogamous domestic populations are a mixture of pure lines in terms of agriculture, pathology and quality. These are expected to be more heterogeneous than the breeding varieties. Genetic diversity decreased with the replacement of new breeding varieties and conventionally cultivated domestic varieties and this caused the genotypes in the population to become genetically and morphologically uniform. Molecular characterization of breeding materials is essential for breeders, germplasm collections and the commercial sector, such as nurseries. The identification of genotypes provides a standardizable reference for the identification of any genotype, regardless of any factors that limit or influence phenotypic characterization, such as environmental factors, the time of year or the age of the plant material. Furthermore, the possibility of studying the genetic diversity among different cultivars and populations will benefit tomato breeding programs by helping to take decisions on parental genotypes for crosses, and germplasm management to maximize diversity. This is becoming increasingly important to conserve the existing variability in the wild stands of this species scattered throughout most European and some Asian countries, especially due to the progressive narrowing of the genetic base. In this study, we employed RAPD and SRAP markers to evaluate polymorphisms among tomato genotypes, which were obtained from our breeding program (Figure 2). Our results indicated that RAPD and SRAP markers are useful tools for tomato variety 
identification. The advantages of RAPD and SRAP molecular techniques include the ability to detect extensive polymorphisms, simplicity, rapidity and without the need for radioisotopes.

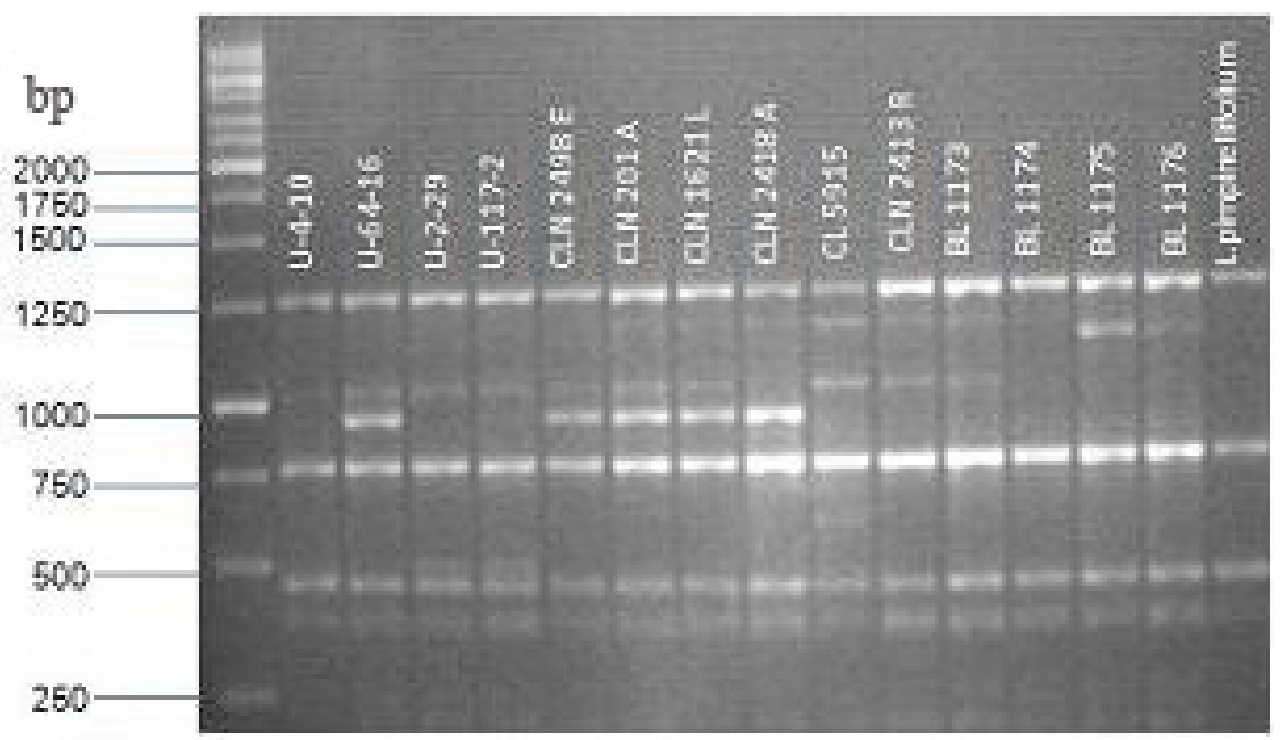

Figure 2. Polymorphic RAPD-agarose gel image.

The same group of tomato lines (except for S. pimpinellifolium) were characterized and evaluated by means of the pollen performances and fruit-set characters at high temperature in our previous studies and similarity among genotypes differed depending on traits (Soylu and Comlekcioglu, 2009; Comlekcioglu and Soylu, 2010). Although genotypes characterized in this study exhibited a great deal of morphological variation, they seem to have a relatively limited polymorphism level of RAPD and SRAP primers. There may indeed be limited genetic variation among those genotypes. The results of this study show that similarity ratio of the genotypes studied is high and varied between 0.87 and 0.99 based on molecular markers. We believe that both morphological-agronomic traits and molecular characterization are needed in the quantification of diversity and discrimination. The domestic genotypes could be a valuable source of heat tolerance genes for the genetic improvement of tomato.

\section{REFERENCES}

Aka-Kacar Y, Demirel A, Tuzcu O, Yesiloglu T, et al. (2005). Preliminary results on fingerprinting lemon genotypes tolerant to mal secco (Phoma tracheiphila Kanc. et Ghik) disease by RAPD markers. Biologia 60: 295-300.

Alvarez AE, Van de Wiel CCM, Vosman B and Smulders MJM (2001). Use of microsatellites to evaluate genetic diversity and species relationships in the genus Lycopersicon. Theor. Appl. Genet. 103: 1283-1292.

AVRDC (2001). Asian Vegetable Research and Development Center. In: AVRDC Report 2000 Shanhua, Tainan, Taiwan, vii +152 .

Barrero LS and Tanksley SD (2004). Evaluating the genetic basis of multiple-locule fruit in a broad cross section of tomato cultivars. Theor. Appl. Genet. 109: 669-679.

Breto MP, Asins MJ and Carbone EA (1993). Genetic variability in Lycopersicon species and genetic relationships. Theor. Appl. Genet. 86: 113-120. 
Camejo D, Rodriguez P, Morales MA, Dell'Amico JM, et al. (2005). High temperature effects on photosynthetic activity of two tomato cultivars with different heat susceptibility. J. Plant Physiol. 162: 281-289.

Carelli BP, Gerald LTS, Grazziotin FG and Echeverrigaray S (2006). Genetic diversity among Brazilian cultivars and landraces of tomato Lycopersicon esculentum Mill. revealed by RAPD markers. Genet. Resour. Crop Evol. 53: 395-400.

Comlekcioglu N and Soylu MK (2010). Determination of high temperature tolerance via screening of flower and fruit formation in tomato. J. Agric. Sci. 20: 123-130.

Edwards K, Johnstone C and Thompson C (1991). A simple and rapid method for the preparation of plant genomic DNA for PCR analysis. Nucleic Acids Res. 19: 1349.

Firon N, Shaked R, Peet MM, Phari DM, et al. (2006). Pollen grains of heat tolerant tomato cultivars retain higher carbohydrate concentration under heat stress conditions. Sci. Hortic. 109: 212-217.

Foolad MR (2007). Genome mapping and molecular breeding of tomato. Int. J. Plant Genomics 2007: 64358.

Gepts P (2002). A comparison between crop domestication, classical plant breeding, and genetic engineering. Crop Sci. 42: $1780-1790$.

Gepts P (2006). Plant genetic resources conservation and utilization: the accomplishments and future of a societal insurance policy. Crop Sci. 46: 2278-2292.

Heywood V, Casas A, Ford-Lloyd B, Kell S, et al. (2007). Conservation and sustainable use of crop wild relatives. Agric. Ecosyst. Environ. 121: 245-255.

Houghton J and Yihui D (2001). Summary for Policymakers: Climate Change 2001: The Scientific Basis - A Report of Working Group I of the Intergovernmental Panel on Climate Change. Available at [http://www.grida.no/CLIMATE/ IPCC_TAR/wg1/pdf/WG1_TAR-FRONT.PDF].

IPCC (Intergovernmental Panel on Climate Change) (2001). Climate Change Impacts, Adaptation and VulnerabilityTechnical Summary. Available at [http://www.ipcc.ch/pdf/climate-changes-2001/synthesis-syr/english/wg2-technicalsummary.pdf].

IPGRI (International Plant Genetic Resources Institute) (1996). Tomato Descriptors. International Plant Genetic Resources Institute, Rome.

Li G and Quiros CF (2001). Sequence-related amplified polymorphism (SRAP) a new marker system based on a simple PCR reaction: its application to mapping and gene tagging in Brassica. Theor. Appl. Genet. 103: 455-461.

Li-Wang L, Wang Y, Gong Y, Zhao T, et al. (2007). Assessment of genetic purity of tomato (Lycopersicon esculentum L.) hybrid using molecular markers. Sci. Hortic. 115: 7-12.

Mantel N (1967). The detection of disease clustering and a generalized regression approach. Cancer Res. 27: 209-220.

Meehl GA, Stocker TF, Collins WD, Friedlingstein P, et al. (2007). Global Climate Projections. In: Climate Change 2007: The Physical Science Basis. Contribution of Working Group I to the Fourth Assessment Report of the Intergovernmental Panel on Climate Change (Solomon S, Qin D, Manning M, Chen Z, et al., eds.). Cambridge University Press, Cambridge.

Miller JC and Tanksley SD (1990). RFLP analysis of phylogenetic relationships and genetic variation in the genus Lycopersicon. Theor. Appl. Genet. 80: 437-448.

Peet MM, Sato S and Gardner RG (1988). Comparing heat stress on male-fertile and male-sterile tomatoes to chronic, sub-acute high temperature stress. J. Exp. Bot. 21: 225-231.

Peet MM, Willits DH and Gardner RG (1997). Responses of ovule development and post pollen production processes in male-sterile tomatoes to chronic, sub-acute high temperature stress. J. Exp. Bot. 48: 101-111.

Rohlf FJ (1998). NTSYS-pc Numerical Taxonomy and Multivariate Analysis System. Version 2.00. Exeter Software, Setauket, New York.

Saliba-Colombani V, Causse M, Gervais L and Philouze J (2000). Efficiency of RFLP, RAPD, and AFLP markers for the construction of an intraspecific map of the tomato genome. Genome 43: 29-40.

Sato S, Peet MM and Gardner RG (2001). Formation of partenocarpic fruit, undeveloped flowers and aborted flowers in tomato under moderately elevated temperatures. Sci. Hortic. 90: 243-254.

Soylu MK and Comlekcioglu N (2009). The effects of high temperature on pollen grain characteristics in tomato (Lycopersicon esculentum M). J. Agric. Fac. HR. U. 13: 35-42.

Strauss DG (1991). Biodiversity. Vol. 7, No. 3. A News Journal for the International Plant Genetic Resources Community. Genetic Resources Communications Systems, Inc. ISSN: 0744-8163.

Taylor IB (1986). Biosystematics of Tomato. In: The Tomato Crop - a Scientific Basis for Improvement (Atherton JG and Rudich J, eds.). Chapman and Hall Ltd., New York.

Terzopoulos PJ and Bebeli PJ (2008). DNA and morphological diversity of selected Greek tomato (Solanum lycopersicum L.) landraces. Sci. Hortic. 116: 354-361. 
Thomas JMG and Prasad PVV (2003). Plants and the Environment/Global Warming Effects. University of Florida, Gainesville.

Uzun A, Yesiloglu T, Aka-Kacar Y, Tuzcu O, et al. (2009). Genetic diversity and relationships within Citrus and related genera based on sequence related amplified polymorphism markers (SRAPs). Sci. Hortic. 121: 306-312.

Wahid A, Gelani S, Ashraf M and Foolad MR (2007). Heat tolerance in plants: an overview. Environ. Exp. Bot. 61: 199-223.

Warner RM and Erwin JE (2005). Naturally occurring variation in high temperature induced floral bud abortion across Arabidopsis thaliana accessions. Plant Cell Environ. 28: 1255-1266. 